\title{
Evaluation of suitability of land use to area function direction in Tangka Watersheds, South Sulawesi, Indonesia
}

\author{
Muh. Aqsa Jamaluddin', Usman Arsyad², Muchtar Salam Solle ${ }^{3}$ \\ ${ }^{1}$ Environmental Management Study Program of Graduate School, Hasanuddin University \\ ${ }^{2}$ Department of Watershed Management, Faculty of Forest, Hasanuddin University \\ ${ }^{3}$ Department of Soil Science, Faculty of Agriculture, Hasanuddin University
}

Correspondence Author: Muh. Aqsa Jamaluddin, Environmental Management Study Program of Graduate School, Universitas Hasanuddin, Indonesia.

Email: muh.aqsa31@gmail.com

Received date: 12 December 2019, Accepted date: 28 March 2020, Online date: 14 April 2020

Copyright: (C), 2020, Muh. Aqsa Jamaluddin et al. This is an open-access article distributed under the terms of the Creative Commons Attribution License, which permits unrestricted use, distribution, and reproduction in any medium, provided the original author and source are credited.

\begin{abstract}
Watersheds have various benefits for life, including the use of water for irrigation, agriculture, household consumption, river transportation, and other needs. However, if there is no proper management in the watershed, it will have an adverse impact or threat of disasters such as floods, erosion and landslides. Thus the purpose of this study is to examine the suitability of land use to the direction of the function of the area in the Tangka watershed. Secondary data collection in the form of land type data, rainfall, slope and land use was conducted in December 2019. The method used in this study is the Geographic Information System method with scoring and overlay techniques using ArcGIS software. The results showed that there was $39,325.80 \mathrm{Ha}(\mathbf{8 1 . 5 0 \%})$ land-use area that was still under the direction of the area's function and land use that was not under the course of the area's function had an area of $8,925.86 \mathrm{Ha}(\mathbf{1 8 . 5 0 \%})$. One of the causes of land use mismatch is the lack of community understanding of the spatial and territorial patterns in the Tangka watershed.
\end{abstract}

Keywords: Land Use, Area Function Direction, Watersheds, Geographic Information Systems

\section{INTRODUCTION}

Land-use change is a complex process that can affect erosion and sediment load rates in a watershed [1]. Thus, causing changes in ecosystems and functions [2.] Problems in watersheds are caused by climate and some human activities [3] due to an increase in the human population and high economic opportunity responses in the region [4]. Thus, the land is under high pressure due to land conversion by urbanization and industrialization [5] [6].

One of the Watersheds in South Sulawesi, Indonesia, is of concern because of the frequent occurrence of floods and landslides during the rainy season, namely the Tangka watershed. In addition, to be a water catchment area, the Tangka watershed is an agricultural area that is used intensively in the upstream area so that it impacts on sedimentation and erosion. If there is damage due to land conversion that is not under the regional spatial plan, it will have an impact on the downstream area [7]. Guidelines for determining the direction of land use are spatial planning based on the primary function of the area, namely, the role of protected areas and cultivation areas [8]. To determine the direction of regional services is done by making a map using the Geographic Information System (GIS) method. This is under the research that focuses on the spatial assessment of land-use conflicts related to environmental problems and their exchange with economic and ecological returns [9]. This study will examine the suitability of land use in the direction of regional functions in the Tangka watershed.

\section{RESEARCH METHODS}

This research was conducted in the Tangka watershed in two administrative regions, namely Sinjai Regency and Gowa Regency, South Sulawesi. The population in this study is the current land use in the Tangka watershed by taking a sample of 90 points representing the entire population. The technique used in this research is purposive sampling technique. Data collection uses field survey techniques and documentation. The data used in this study are secondary data that includes data on soil type, slope, rainfall, and land use. The tools used are Laptop, ArcGis Software, Global Positioning System (GPS), and Camera. 


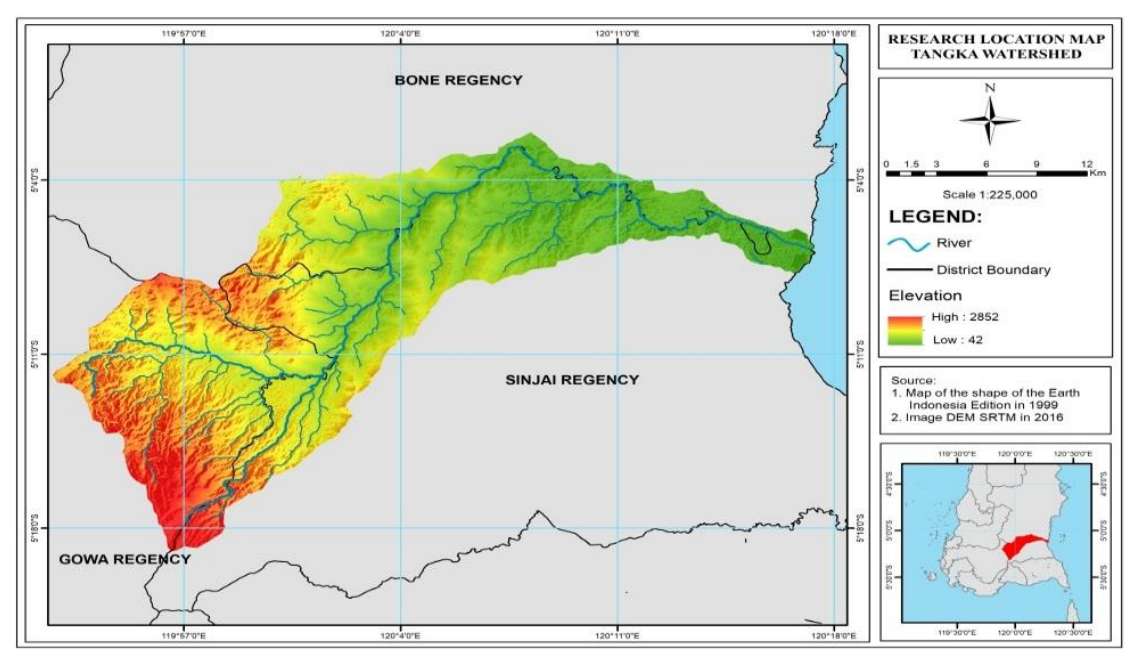

Fig. 1: Location map of the Tangka Watershed Research

The data analysis technique in this study is the scoring and overlay technique. Scoring in this study is intended to provide a score (weight) score for each factor determining the criteria for determining the function of the area. The scoring for slope factors can be done based on Table $1[10]:$

Table 1: Classification and score of slope factors

\begin{tabular}{|c|c|c|c|c|}
\hline Number & Class & Slope (\%) & Description of & Score \\
\hline 1 & I & $0-8$ & Very Sloping & 20 \\
\hline 2 & II & $8-15$ & Sloping & 40 \\
\hline 3 & III & $15-25$ & Somewhat Steep & 60 \\
\hline 4 & IV & $25-45$ & Steep & 80 \\
\hline 5 & V & $>45$ & Very Steep & 100 \\
\hline
\end{tabular}

Parameters the second physical formulation of the direction of the function of the Region is the intensity of rainfall. Giving scoring to factor intensity of precipitation can be performed based on Table 2 [10]:

Table 2: Classification and score factor soil types

\begin{tabular}{|c|c|c|c|c|}
\hline Number & Class & Soil Type & Description & Score \\
\hline 1 & I & Alluvial Land Gley, Planosol, Hodromof, Gray, laterite Groundwater & Insensitive & 15 \\
\hline 2 & II & Latosol & Not Sensitive & 30 \\
\hline 3 & III & Brown Forest, Non-Celtic Brown, Mediterranean & Sensitive & 45 \\
\hline 4 & IV & Andosol, Lateric, Chromosol, Podsol, Podsoltic & Sensitive & 60 \\
\hline 5 & V & Regosol, Litosol, Organol, Renzina & Very Sensitive & 75 \\
\hline
\end{tabular}

The third physical parameter in the preparation of the directives function Area island type. Scoring for soil type factors can be done based on Table 3 [10]:

Table 3: Classification and score factors Daily Intensity of Rainfall

\begin{tabular}{|c|c|c|c|c|}
\hline Number & Class & Interval(mm / day) & Description of & Scores \\
\hline 1 & I & $0-13.6$ & Very Low & 10 \\
\hline 2 & II & $13.6-20.7$ & Low & 20 \\
\hline 3 & III & $20.7-27.7$ & Medium & 30 \\
\hline 4 & IV & $27.7-34.8$ & High & 40 \\
\hline 5 & V & $>34.8$ & Very high & 50 \\
\hline
\end{tabular}

In determining the direction of the function of the utilization area, three physical parameters are added later adjusted to the scoring table criteria for the course of the function area. The scoring for the area function direction criteria can be done based on Table 4 [10]:

Table 4: Score Criteria for the area function direction

\begin{tabular}{|c|c|c|}
\hline Number & Zone & Score \\
\hline 1 & Protected area & $>175$ \\
\hline 2 & Supporting area & $125-175$ \\
\hline 3 & Annual crop cultivation area & $<125 \&$ Slope $>8 \%$ \\
\hline 4 & Seasonal cultivation area and settlement area & $<125 \&$ Slope $\leq 8 \%$ \\
\hline
\end{tabular}


Distance in some local protected areas can be seen in Table 5 [10]:

Table 5: Types of Local Protected Areas

\begin{tabular}{|c|c|c|}
\hline Number & Types of Protected Areas Local & Border Borders \\
\hline 1 & Altitude> 2000 masl & - \\
\hline 2 & Springs & $200 \mathrm{~m}$ \\
\hline \multirow{3}{*}{3} & Big River & $50 \mathrm{~m}$ \\
\cline { 2 - 3 } & Small River & $20 \mathrm{~m}$ \\
\cline { 2 - 3 } & River in Settlement & $15 \mathrm{~m}$ \\
\hline 4 & Lake & $100 \mathrm{~m}$ \\
\hline
\end{tabular}

The subsequent data analysis is the map overlay, which is done in stages. The first step is to put together several maps, which are maps of soil types, slope and rainfall, which will produce a plan of the main functions of the area. The second stage is overlaying the direction map of the main tasks of the region with a land-use map, which results in a sheet of suitability.

\section{RESULTS}

\section{Land Use}

Results of interpretation of Landsat 8 satellite imagery in 2018 and the effects of field observations note that there are nine land uses in the Tangka watershed can be seen in Table 6.

Table 6: Land Use in Tangka Watershed

\begin{tabular}{|c|c|c|c|}
\hline Number & Land Use & Area (Ha) & Percentage (\%) \\
\hline 1 & Water Agency & 699.37 & 1.45 \\
\hline 2 & Mangrove Forest Secondary & 60.81 & 0.13 \\
\hline 3 & Primary forest & 9590.82 & 19.88 \\
\hline 4 & Plantation Forests & 5819.38 & 12.06 \\
\hline 5 & Settlement & 1463.20 & 3.03 \\
\hline 6 & Dryland Agriculture & 14402.23 & 29.85 \\
\hline 7 & Rice & 4222.12 & 8.75 \\
\hline 8 & Shrublands & 11591.34 & 24.02 \\
\hline 9 & Pond & 402.39 & 0.83 \\
\hline & Total & 48251.67 & 100 \\
\hline
\end{tabular}

Type of land use Table 6 shows the most extensive distribution of dryland agriculture with an area of 14,402.23 ha (29.85\%) following shrubs with an area of $11,591.34$ ha $(24.02 \%)$. While the delivery of the smallest land use is a secondary mangrove forest with an area of 60.81 ha $(0.13 \%)$, the distribution of land use resulting from image interpretation in the Tangka Watershed can be seen in Figure 2.

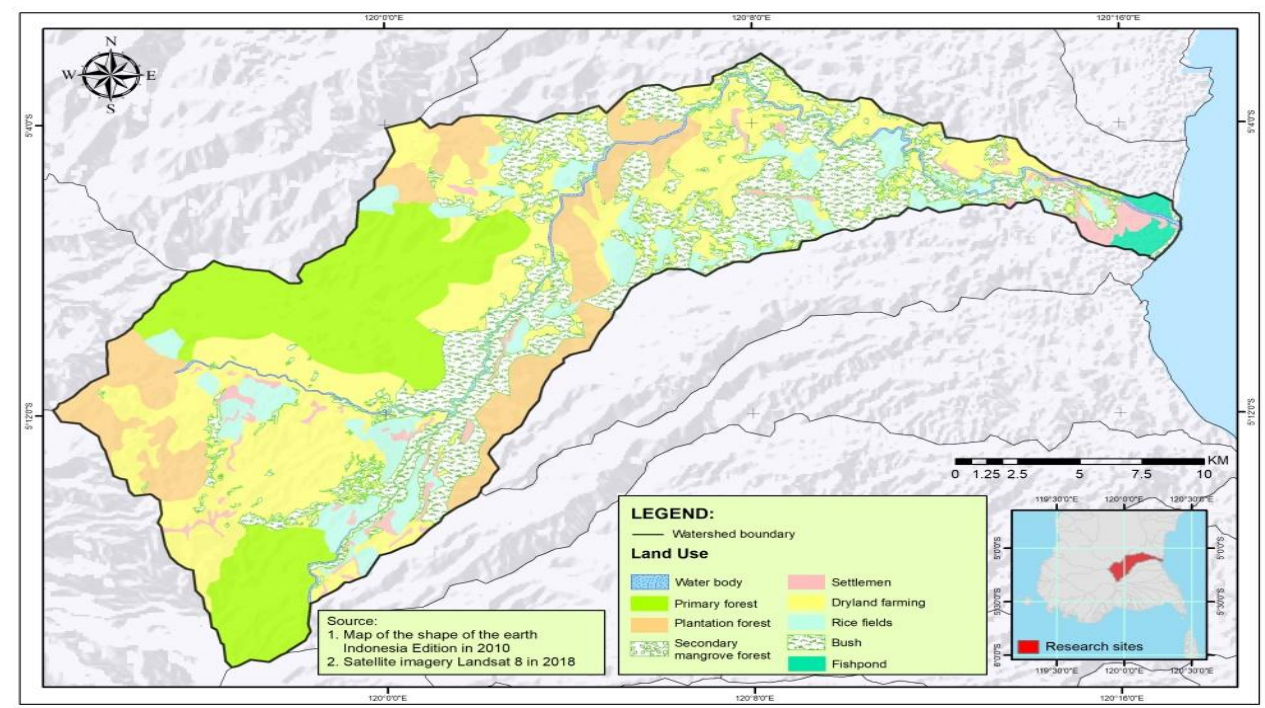

Fig. 2: Land use map in the Tangka Watershed

Area Function Direction

Results of scoring three parameters for the arrangement of area function directives, namely soil type, rainfall and slope using Geographic Information Systems (GIS), produce four guidelines of the function of the area, including the daze, buffer zone, 
annual crop cultivation area and annual crop cultivation area and settlement. A description of the direction of the area function can be seen in Table 7 .

Table 7: Function Direction of Tangka Watershed Area

\begin{tabular}{|c|c|c|c|}
\hline Number & Direction & Area (Ha) & Percentage (\%) \\
\hline 1 & Annual Plant Cultivation Area & 21511.43 & 44.58 \\
\hline 2 & Annual Plant Cultivation Area and Settlement Area & 11340.13 & 23.50 \\
\hline 3 & Protected Areas & 1116.796 & 2.31 \\
\hline 4 & Buffer Area & 14283.31 & 29.60 \\
\hline \multicolumn{2}{|c|}{ Total } & 48251.67 & 100 \\
\hline
\end{tabular}

The direction of the function of the area in table 7 shows that the most significant area is the area of annual crop cultivation, with an area of $21,511.43$ ha $(44.58 \%)$. While it has been reported has the lowest area is protected forest area with an area of $1,116.79$ ha $(2.31 \%)$. Distribution landing area function ArcGIS software overlay on the results can be seen in Figure 3.

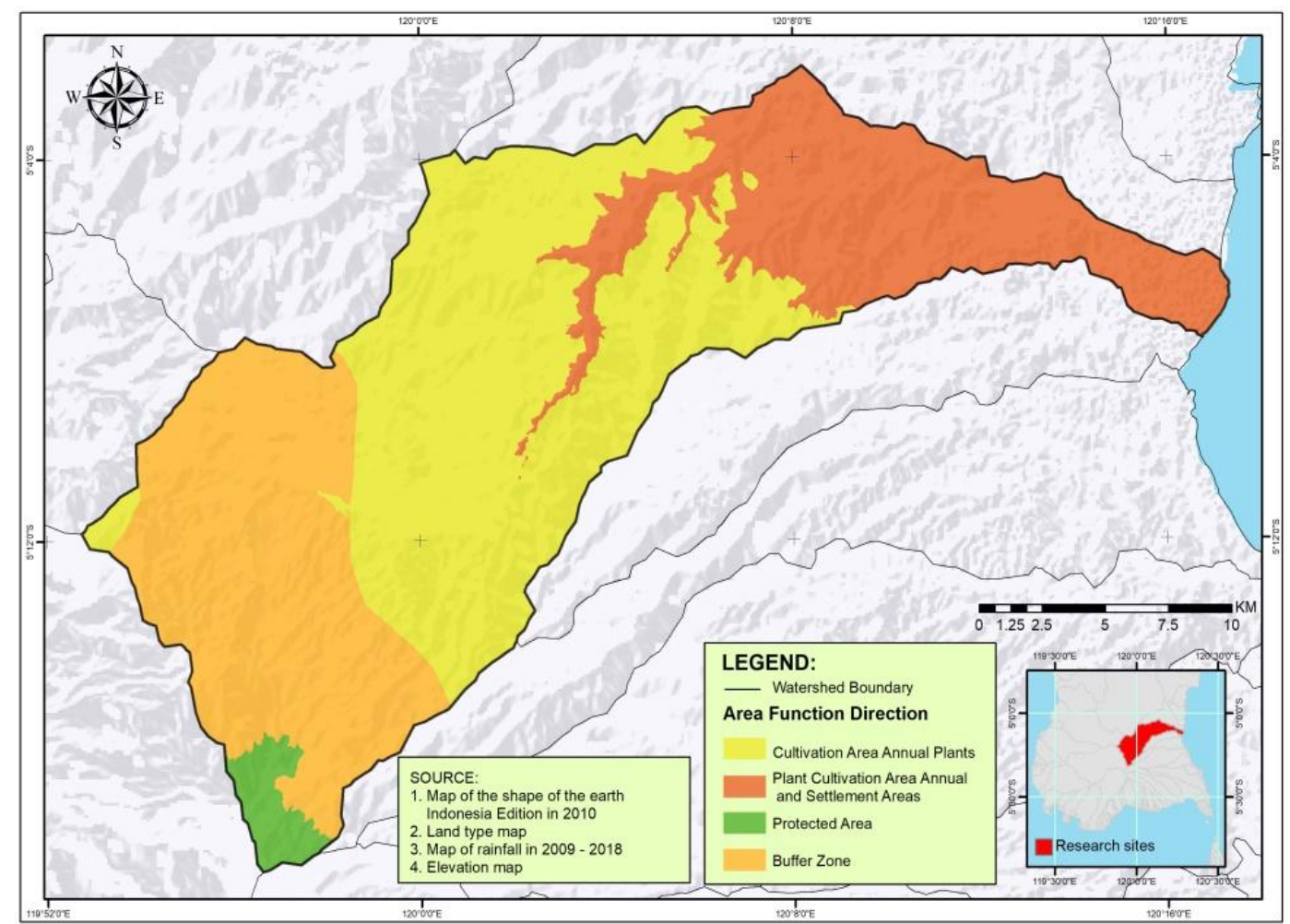

Fig. 3: Map of Tutorial Function in the Tangka Watersheds

Land Use Suitabilityagainst Tutorial Function Zone

Land-use suitability analysis results obtained from the analysis of overlay between land use under the guidance function in the watershed area Tangka. The results of the overlay can be seen in Table 8 .

Table 8: Conformity of Land Use to Direction Function of Tangka Watershed Area

\begin{tabular}{|c|c|c|c|}
\hline Number & Conformity & Area (Ha) & Percentage (\%) \\
\hline 1 & In accordance & 39325.80 & 81.50 \\
\hline 2 & Not in Accordance & 8925.86 & 18.50 \\
\hline \multicolumn{2}{|l}{ Total } & 48251.67 & 100.00 \\
\hline
\end{tabular}

Based on table 8, land use by directives, the area function has an area of 39,325.80 Ha (81.50\%), and land use that is not by the direction of the area function has an area of 8,925.86 Ha (18.50\%). The sum of land-use suitability can be seen in Figure 4. 


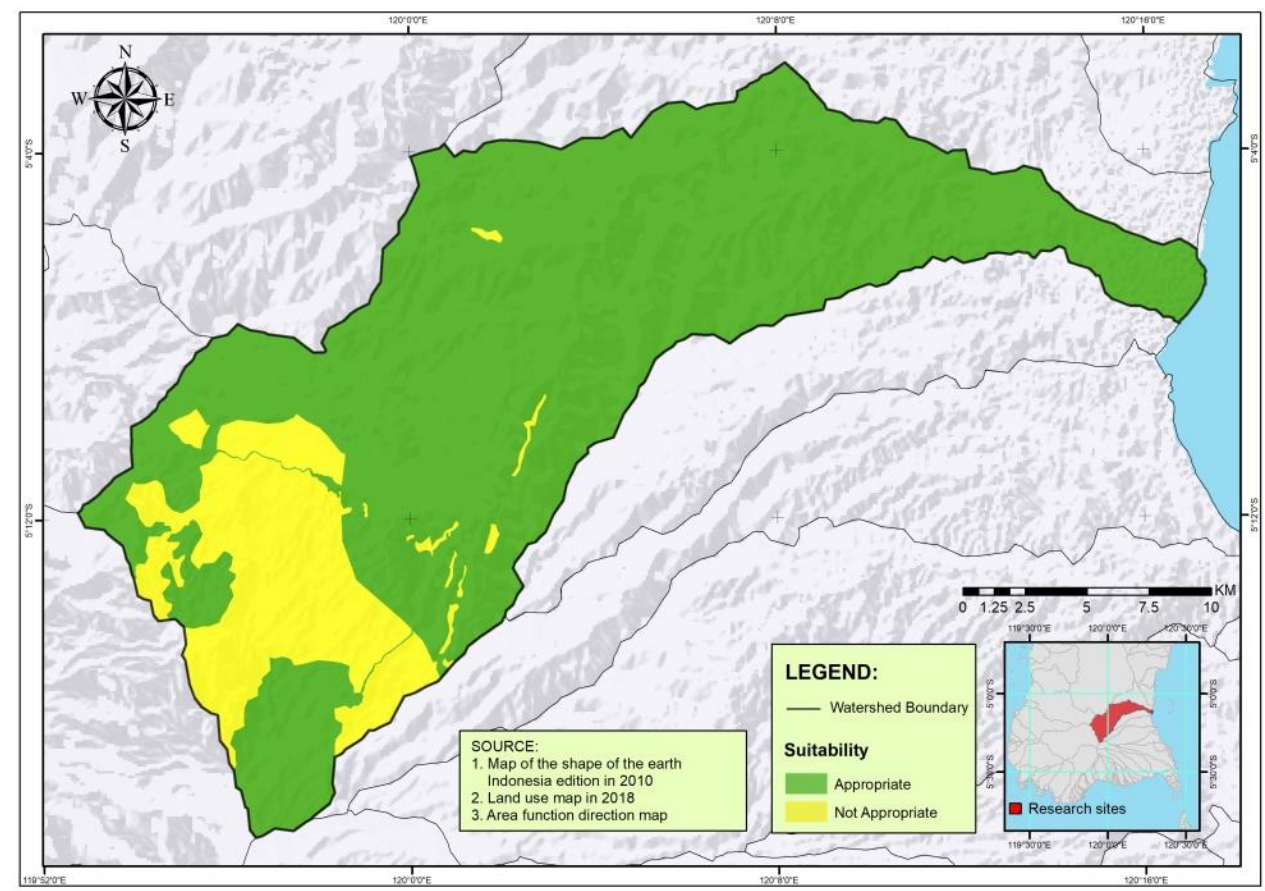

Fig. 4: Land Use Conformity Map Tangka

\section{DISCUSSION}

Results of land use classification in 2018 will then be tested for the accuracy of classification results. The level of mastery of interpretation performed using a confusion matrix table is $92.2 \%$. The number of sample points taken was 90 points with the number of suitable sample points in the field as many as 83 points, and the number of samples that did not fit in the area was 7 points. Then the results of image interpretation carried out are accepted by Lillesand and Kiefer (1997) [11].

In the land suitability percentage of $18.50 \%$ which is not suitable, this is due to the use of land that is not by its designation such as in a protected area there is a dry land agriculture area of $71.75 \mathrm{Ha}$. In the buffer zone, there are rice fields, dryland agriculture, bush grove and settlement. Intensive agricultural activities in the upstream area can cause a decrease in water quality in the downstream area [12] [13].

Interviews with several community leaders revealed that there was a lack of community understanding of spatial planning in the Tangka watershed. The government is only focused on developing agriculture to improve the welfare of the community. Lack of socialization to the community about the importance of conservation is also an obstacle in overcoming the problem of nonfunctioning regional functions.

Much research has been done on the impact of land use on hydrological changes, water quality, and erosion in watersheds [15]. These studies explain that the hydrological cycle and erosion process are closely related to land-use change. And a survey by Cuo (2016) on the effects of urbanization on hydrology explains that an increase in human settlements leads to a decrease in infiltration and an increase in sediment runoff [16].

\section{CONCLUSION}

Based on the results of the study, it can be concluded that there is a discrepancy in the use of land to the direction of the function of the area in the Tangka Watershed by $18.50 \%$ in protected areas, buffer zones and annual crop cultivation areas. Lack of socialization regarding spatial planning is one of the causes of land use mismatches. So that proper coordination is needed between the government and the local community in managing watersheds.

\section{ACKNOWLEDGEMENT}

Author thanks, Nur Akifah and Warren C. Montalobo for their support and assistance in conducting research.

\section{REFERENCES}

[1] Abdelwahab, OMM, Bisantino, T., Milillo, F., Gentile, F., 2013. Runoff and sediment yield modelling in a medium-size Mediterranean watershed.J. Agric. Eng. Res, 44:31-40.

[2] Kim, I., Amhold, S., 2018. Mapping environmental land use potential conflicts and ecosystem services in agricultural watersheds.Science of the Total Environment. 630:827-838. 
[3] Leh, M., Bajwa, S., Chaubey, I., 2013. Impact of land-use change on erosion risk: an integrated remote sensing, geographic information systems and modelling methodology.Land Degradation, 24:409-421.

[4] Chung, E., Park, K., Lee, KS, 2011. The relative impacts of climate change and urbanization on the hydrologic response of a Korean urban watershed.Hydrol Process, 25:544-560.

[5] Vasu, D., Srivastava, R., Patil, NG, Tiwary, P., Chandran, P., Singh, SK, 2018. A comparative assessment of land suitability evaluation methods for agricultural land use planning at the village level.Land Use Policy, 79:146-163.

[6] Erickson, DL, Lovell, SL, Méndez, VE, 2013. Identifying, quantifying and classifying agricultural opportunities for land use planning.Landsc. Urban Plan, 118: 29-39.

[7] Arsyad, U., Soma, US, Wahyuni, Arief, TR., 2017. Conformity and Direction of Land Use Based on the Regional Spatial Pattern Plan in the Upper Kelara River Basin.Forest and Community Journal, 9 (2): 75-82.

[8] Law of the Republic of Indonesia Number 26 of 2007 concerning Spatial Planning, 2007. Jakarta.

[9] Goldberg, CS, Pocewicz, A., Nielsen-Pincus, M., Waits, LP, Morgan, P., Force, JE, Vierling, LA, 2011. Predictions of ecological and social impacts of alternative residential development policies to inform decision making in a rural landscape.Conserv. Lett, 4: 423-432.

[10] Decree of the Minister of Agriculture No. 683 / Kpts / Um / 8/1981 concerning Criteria and Procedures for Establishing Protection of Forests and Production Forests. 1990. Jakarta.

[11]Lillesand, TM., And RW Kiefer, 1997. Remote Sensing and Image Interpretation.Gajah Mada University Press. Yogyakarta.

[12] Valle Junior, RF, Varandas, SGP, Sanches Fernandes, LF, Pacheco, FAL, 2014. Environmental land use conflicts: a threat to soil conservation.Land Use Policy, 41: 172-185.

[13] Pacheco, FAL, Sanches Fernandes, LF., 2016. Environmental land-use conflicts in catchments: a significant cause of amplified nitrate in river water.Sci Total Environ, 548-549:173-188.

[14] Wang, X., Zhao, X., Zhang, Z., Yi, L., Zuo, L., Wen, Q., Liu, F., Xu, J., Hu, S., Liu, B., 2016. Assessment of soil erosion change and its relationships with land use/cover change in China from the end of the 1980s to 2010.Catena, 137: 256268.

[15] Cuo, L., 2016. Land use/cover change impacts on hydrology in large river basins: a review.Terrestrial Water Cycle and Climate Change: Natural and Human-Induced Impacts, 221, 103. 